\title{
Update in the editorial policy of the Arquivos do Instituto Biológico: align with Open Science and Good Editorial Practices
}

\author{
Simone Bacilieri ${ }^{1, *}$ (1) https://orcid.org/0000-0002-3684-4411 \\ Silvia Galleti ${ }^{1}$ (D) https://orcid.org/0000-0002-0745-5716 \\ 1. Instituto Biológico, Agência Paulista de Tecnologia dos Agronegócios, Secretaria de Agricultura e Abastecimento do Estado de \\ São Paulo, São Paulo (SP), Brazil \\ *Corresponding author: simone.bacilieri@sp.gov.br
}

Arquivos do Instituto Biológico (AIB) is a 93-year-old journal of Agricultural Sciences. It has been open and free access since 2000. In 2012, the AIB was indexed in the SciELO Brazil Collection, which led to the improvement and professionalization of its policy, aiming to meet the Good Editorial Practices. Galleti et al. (2021) reported the actions taken by the AIB recently to improve elements aimed at complying with good practices and complying with SciELO Brazil guidelines for the admission and permanence of journals in the Collection (SCIELO BRASIL, 2021). They were:

- Editorial policy review: the AIB revised and adjusted its scope and editorial policy. The greater clarity given to this item supported the rejections of the manuscripts upon submission. AIB also started to request a cover letter. The content of this letter reveals the quality of the work, also allowing the Editor-in-Chief or Sector Editor to act to interrupt the processing of a manuscript that would not meet the journal's expectations in terms of scientific merit. The issue of scientific integrity also became more explicit in the AIB's editorial policy. Authors must submit a document declaring that the manuscript is unpublished, prepared without fraud and/or derivations of plagiarism, in addition to assuming that the content is their entire responsibility, including in cases of retraction. Additionally, authors are informed that the manuscript will be submitted to a similarity detection program. In this case, when a significant similarity index is detected, the manuscript is immediately rejected. Manuscript rejections upon submission lead to an improvement in the quality of the journal, as there is a guarantee that only the good ones are processed, and the best ones are published. In doing so, we are also preserving associate editors and scientific reviewers (ad hoc) who provide a valuable service, but without remuneration.

- Attribution of Creative Commons License: AIB, with the guidance and encouragement of SciELO Brazil, adopted the CC-BY license. This license is the standard used by SciELO, where journals are published in open access in the golden modality, that is, without any embargo. With this action, the AIB declares itself to be a supporter of the Open Science movement, thus allowing access to the full texts, downloading the article, sharing it with other users, producing derivatives and republishing at no cost, provided that the original is duly cited, in particular, acknowledging the authors, the journal and a link to the text. The CC-BY license qualifies the article as a public good.

- Indexing in Directory of Open Access Journal (DOAJ): DOAJ is the international reference directory for the registration of open access journals that comply with good editorial practices. The AIB sought its indexing in this directory and, with this, confirms that it is not a predatory journal, promoting the reliability of authors who choose to publish their research results in it.

- Adoption of the Digital Object Identifier (DOI): in 2015, in a joint action with SciELO Brazil, the AIB started to assign the DOI persistent identifier to all its published articles. With this achievement, the AIB promoted a facilitator for the localization of its publications online, also allowing its authors to count the citations received by the work and, also, increasing the visibility and guaranteeing the authenticity of the publication.

- Adoption of the Open Researcher and Contributor ID (ORCID): the persistent digital identifier of researchers is unique and free, which distinguishes one researcher from another and solves the problem of ambiguity and 
similarity of the names of authors and individuals, replacing name variations with a single numeric code, facilitating the registration of information and automating updating publications. In 2018, AIB began a process of encouraging authors to provide their ORCID, obtaining a very positive response from them. As of 2019, the AIB works publish the ORCIDs of $100 \%$ of their authors.

- Adoption of the CRediT taxonomy: In order to meet this SciELO Brazil criterion, in 2019, the AIB started to demand, at the time of manuscript submission through the ScholarOne system, the contribution of each author to the work in question. For this, the AIB chose to use the CRediT taxonomy. In this taxonomy, there are 14 collaboration functions, which are assigned to authors according to their participation.

- Digital Scientific Dissemination: Following SciELO Brazil's guidance, AIB created, in 2015, profiles on Facebook and Twitter (@ArquivosIB), aiming to increase the reach and impact of its publications, measuring altimetric indices to the articles. These media are also used to update and sensitize their followers to questions about scientific writing, good research practices, etc. AIB is also present on Mendeley, sharing all its articles since 2012.

Today, AIB is a publication $100 \%$ in English and organized to maintain the Good Editorial Practices already achieved. Since 2015, it has been continuously publishing its articles, thus accelerating the communication of research. In 2020, the layout of published articles was changed, incorporating information on conflicts of interest, authors' contributions, funding, data statement availability of research and approval by the ethics committee. A new revision of the Editorial Policy was carried out in order to take the first steps within Open Science, an international movement that proposes structural changes in the way scientific knowledge is produced, organized, shared and reused, understood as a new way of doing science - more collaborative, transparent and sustainable (FIOCRUZ, 2020). The AIB started to encourage authors to practice preprint, to enter the URL of their research data deposit, and we started to raise awareness for future openness of peer reviews. Given these practices, we can conclude that the AIB is aligned with open science and, therefore, is committed to speeding up research communication, bringing the necessary transparency to the entire editorial process.

\section{REFERENCES}

FIOCRUZ. Política de gestão, compartilhamento e abertura de dados para pesquisa: princípios e diretrizes. Rio de Janeiro: Fiocruz/ VPEIC, 2020. 19p. Available from: https://www.arca.fiocruz.br/bitstream/icict/46408/2/VPEIC_versao_PORTUGUES_2021-03-22.pdf. Access on: 12 abr. 2021

GALLETI, S.; BACILIERI, S.; VIEIRA, E.; FERNANDES; M.J.B. Das boas práticas editoriais à ciência aberta: o caminhar de um periódico brasileiro. Páginas a\&b, S.3, no especial ConfOA (2021), p.260-261, 2021. Available from: https://brapci.inf.br/index.php/res/v/157281. Access on: 12 abr. 2021

SCIELO BRASIL. Critérios, política e procedimentos para a admissão e a permanência de periódicos na Coleção SciELO Brasil. Available from: https://wp.scielo.org/wp-content/uploads/20200500-Criterios-SciELO-Brasil.pdf. Access on: 12 abr. 2021 